\title{
Managing Towards a World that Works for all
}

\section{Michael Pirson ${ }^{1}$}

Published online: 19 July 2019

(C) Springer Nature Switzerland AG 2019

Billionaires of the world are increasingly worried about the state of affairs. Ray Dalio joined a growing chorus of investors that are worried not only about the risks of climate change and other environmental threats (like Mike Bloomberg) but increasing inequality that acts as powder in an increasingly explosive political world. ${ }^{1}$ Management with a capital M, understood as a way of organizing affairs, needs to be refurbished because as a species we are mismanaging.

\section{From Sandwich to Bagel Management}

The current way we understand management has been dominated by a paradigm that works for a few and does not consider the rest. I am using the metaphor of the triangular bologna sandwich standing on its side sloping upwards (the kind of sandwich popular in the United States) as a way to describe how the success of current management models is evaluated MORE is better; more money, more market share, more customers. It represents the idea that all we want is growth, unlimited growth.

To manage for a world that works for all we need to shift the metaphor towards a donut (as Kate Raworth (2017) suggests) or to stay with the sandwich comparison- a wholesome bagel. The currency of success then becomes BETTER - better products, better services, better solutions to problems.

As Raworth (2017) suggests there is a safe and just zone for humanity- a space where we can all thrive. To get there we need better Management and Organizing at the level of humanity. The core of the bagel represents what I call the dignity core, the basic needs all humans need to fulfil to live as humans. The outer boundary of the bagel represents the planetary boundaries that humanity is violating -at our peril.

The editors of this journal argue that the most important task of managers is to 1) move humanity above the dignity threshold (the inner core) and 2) reduce the impact of human

\footnotetext{
${ }^{1}$ https://www.bloomberg.com/news/articles/2019-04-07/dalio-says-capitalism-s-income-inequality-is-nationalemergency
}

Michael Pirson

pirson@fordham.edu

1 Fordham University, New York City, NY, USA 
activity on the planetary boundaries to 3) enable flourishing of all life on earth. We call it the process to get there humanistic management: the protection of dignity and the promotion of well-being.

Once you see the world less like a triangular sandwich that makes the managerial task about growth at all costs you can see different possibilities. Once you see management as a healing task to get humanity back towards flourishing it is fundamentally different. This is truly responsible management.

The articles in this issue all expand and explore the above notion in one way or the other.

\section{Articles: Understanding Responsibility within Differing Paradigms of Management}

Friedrich Glauner (2019) explores the various paradigms and their resulting notions of responsibility. He argues that the economistic paradigm enforces a responsibility gap. As a result, companies are constantly torn between economically rational decisions for the company and a separate logic that is guided by legitimacy along Corporate Social Responsibility. He suggests that a humanistic paradigm of embedded responsibility can lead to future proof decision making. Integral ethical reasoning can guide managerial decision making towards BETTER not just MORE. According to Glauner, any group and organization is adopting that approach towards responsibility is more likely to be viable in the future.

Frederick Ahen (2019) is exploring the implications of responsibility for global companies in an era of resurgent nationalism. He situations his conceptualizations in the context of political unrest which he describes as a quest for freedom, autonomy and dignity. He labels the source of upheaval the wish for stakeownership and he proposes what such a model could look like in a time of "globalisolationism."

María Lucila Osorio Andrade, Sergio Madero and Regina Greenwood (2019) look at a practice called circular migration and how economistic and humanistic approaches towards responsibility can shape it. They explore the temporary migration movements from Mexico to Canada and the United States. They also demonstrate how these temporary job programs violate dignity and prevent human thriving. Finally they propose how these programs could be amended and redesigned to honor dignity and promote well-being (Bagel Management).

Laura Sasse-Werhahn (2019) examines the global reporting initiative as a form of documenting responsibility from a practical wisdom perspective. In an effort to meet growing stakeholder demands for transparency, accountability, and responsibility, many large organizations globally have voluntarily adopted the Global Reporting Initiative (GRI) guidelines. Moreover, triggered by recent management transgressions, the ancient virtue of practical wisdom (phronesis) has gained increased attention from management scholars, who argue that the Aristotelian concept, with its interdisciplinary nature, has the capacity of turning management back into a holistic, contextual, and virtue-orientated practice. Especially the fact that practical wisdom is firmly based on normative values, coupled with the emphasis on experience and practice, makes it well suited as a leitmotif for sustainable and responsible management. This conceptual paper builds on the link between practical wisdom and sustainability. Sasse argues that the GRI may be regarded as an example of procedural practical wisdom in the context of sustainability reporting, specifically in terms of its emphasis on the holistic and situational dimensions, articulated through the concepts of materiality analysis and stakeholder dialogues.

Chris Laszlo (2019) proposes a further development of the notion of humanistic management. Laszlo argues that humanistic management is emerging as a response to the economistic paradigm prevalent in today's business schools, corporations, and society. There are many compelling 
reasons why the economistic paradigm is becoming obsolete, and even dangerous, for business if it is to become an agent of world benefit. The purpose of his article is not to explain these reasons but rather to situate the transition to humanistic management in the context of multiple worldviews. He proposes a historical sequence of worldviews each with its own paradigmatic assumptions about what it means to be human and the nature of the world. The author draws on converging insights between new science and ancient spiritual traditions to outline an emerging quantum worldview. He specifically suggests that integrating elements of the quantum worldview into humanistic management strengthens it in ways that are essential to humankind's ability to shift to full-spectrum flourishing, defined as a world in which people and all life thrive now and across future generations.

\section{Essays: Responsibilization through Music and Story Telling}

In an attempt to find avenues towards more responsible organizing practices, Marcel Meyer (2019) suggests to look back at some of the most human forms of communication - music. While music can be used to influence human beings to do all kinds of things including shopping more or fight better, he explores how music could help to create more ethical organizations.

In a privileged exchange between David Korten (2019) and James Walsh (2019) they explore how novel ways of thinking about organizing can support a world that works for all. David Korten is examining a new theory of community and its pillars. As he suggests:

The proper purpose of any human institution is to improve the lives of the people who depend on it. If we support that proposition, then is there any place for a privatepurpose corporation? The question becomes especially urgent as society and the human species face growing threats.

His essay provides a broad framework for exploring those questions from a humanistic management perspective. It addresses the foundational issue of human purpose, describes the growing momentum for moving societies toward an ecological civilization, and notes the Earth Charter as a valuable source of ethical principles. Finally, it identifies the outcomes the formal institutions of an ecological civilization must serve and concludes with five design principles that these institutions will need to honor to support lives of diversity, beauty, creativity, and meaning for all.

Jim Walsh, an admirer of David Korten, critically explores his propositions. He does agree with David Korten that we need a theoretically sound meta-narrative to articulate the proper place for business in our lives. That said, he argues, this meta-narrative will only come to life when everyone articulates his and her personal narrative, shares it with others (along with its origins and life consequences), and ultimately fine-tunes it into a personal theory-in-use, one that guides everyday decision-making. Jim Walsh shares how he does encourage his students to do exactly that.

Many of us together can create a world that works for all. Enjoy the read!

\section{References}

Ahen, F. 2019. Globalisolationism and its implications for TNCs' global responsibility. Humanistic Management Journal 4 (1). https://doi.org/10.1007/s41463-019-00057-7.

Glauner, F. 2019. The myth of responsibility: On changing the purpose paradigm. Humanistic Management Journal 4 (1). https://doi.org/10.1007/s41463-018-0048-8. 
Korten, D. 2019. What will it take for business to improve lives? Humanistic Management Journal 4 (1). https://doi.org/10.1007/s41463-019-00059-5.

Laszlo, C. 2019. Strengthening humanistic management. Humanistic Management Journal 4 (1). https://oi. org/10.1007/s41463-019-00055-9.

Meyer, M. 2019. The power of music: Can music at work help to create more ethical organizations? Humanistic Management Journal 4 (1). https://doi.org/10.1007/s41463-019-00053-x.

Osorio Andrade, M.L., S. Madero, and R.A. Greenwood. 2019. Humanism under construction: The case of Mexican circular migration. Humanistic Management Journal 4 (1). https://doi.org/10.1007/s41463-01900061-x.

Raworth, K. 2017. Doughnut economics: Seven ways to think like a 21st-century economist. Hartford: Chelsea Green Publishing.

Sasse-Werhahn, L. 2019. The practical wisdom behind the GRI. Humanistic Management Journal 4 (1). https://doi.org/10.1007/s41463-019-00054-w.

Walsh, J.P. 2019. Who will it take for business to improve lives? The "Man" in the Mirror. Humanistic Management Journal 4 (1). https://doi.org/10.1007/s41463-019-00060-y.

Publisher's Note Springer Nature remains neutral with regard to jurisdictional claims in published maps and institutional affiliations. 